\title{
Sagebrush Vole Range Extension and Other Records
}

\author{
by Robert W. Nero, Regina
}

A male Sagebrush Vole (Lagurus curtatus) which was collected about 10 miles southeast of Beechy, Saskatchewan, on June 6,1964 , is the northern-most record for the province and extends the kncwn range by about 60 miles. The nearest locality for which this species has been previously reported is Duncairn Reservoir on Swift Current Creek (Soper, 1961: 35). Soper also collected it north of Maple Creek, at Tenaille Lake; other records are farther south, from Big Muddy Lake west through the prairie dog country (e.g., see Beck, 1958: 37). The species has been recorded in Alberta north and west to Calgary (Hall and Kelson, 1959: 752 ). Our present record is of special interest inasmuch as the vole was collected north of the South Saskatchewan River. It is likely that the species ranges farther along the river to the north and east where there is rather continuous habitat seemingly suitable for this mouse.

According to Soper (1931) the first indication of the presence of this gray, short-tailed mouse in Saskatchewan was secured by an ornithologist, Hamilton M. Laing, who found a specimen in the nest of a Long-eared Owl at Eastend on June 20, 1921; some time later, another ornithologist, Lawrence $B$. Potter, found one at the entrance to a burrow of a Burrowing Owl 15 miles southwest of Eastend. Actually, an earlier specimen was obtained by a third ornithologist! $\mathrm{H}$. Hedley Mitchell collected a male on July 10, 1915, at Wood Mountain, "close to a goose nest", though it was not identified as this species by him. This specimen (skin with skull enclosed) is \#979 in the collection of the Saskatchewan Museum of Natural History. However, it remained for $\mathrm{J}$. Dewey Soper (1931) to provide abundant specimens (33) and information on the basis of collections and studies made in 1927; additional records are cited in a later report (Scper, 1961). Persons not having access to the 1931 issue of the Canadian FieldNaturalist may wish to consult the bulletin by Rand (1948) which gives a brief summary of the habits of this mouse in Saskatchewan as reported by Soper. It was found chiefly in the treeless area of the semi-arid, short grass plains, where there were small cacti and sage brush.

Our specimen of the Sagebrush Vole (also known as Pallid Vole) and several other mice were taken in arid upland prairie habitat between Snakebite Coulee and the South Saskatchewan River; this was outside of the valley on the prairie top. All were captured by hand in the car headlights, a technique which has already been described (Nero, 1959). Curiously, on the night of June 6, the first five mice which we saw, and which were captured, were each a different species. Our catch that night consisted cf: Olive-backed Pocket Mouse (Perognathus fasciatus) (5); Northern Grasshopper Mouse (Onychomys leucogaster) (1); Deer Mouse (Peromyscus maniculatus) (5, and several others seen); Meadow Vole (Microtus pennsylvanicus) (1); and the Sagebrush Vole. On the previous night, on which it was drizzling, we narrowly missed capturing a mouse which was undoubtedly the Western Jumping Mouse (Zapus princeps); in additicn, we caught two Grasshopper Mice, two Pocket Mice, and saw or captured several Deer Mice.

The Grasshopper Mice were kept alive in captivity, and one of them gave birth to six young about 5:15 p.m. on June 8; a second one produced a litter of four about 11:00 a.m. cn June 10. (An interesting account of this carnivorous and insectivorous rodent may be found in Cahalane, 1947.) The Grasshopper Mice and some of the Pocket Mice were captured quite close to the site at which the Saskatchewan Natural History Society was encamped on its annual summer outing. Members who attended may be especially interested in these records of the small mammals of the area. Other species of interest were a Grasshopper Sparrow (Ammodramus savannarum), captured by Robert Taylor on the night of June 5 in the car headlights, and 
a Spadefoot Toad (Scaphiopus bombifrons) found on the camp road by some member of the camp and brought to us in the morning of June 7. These records show that there is a need for far more study of this interesting region. It seems particularly unfortunate that so little collecting and study have been done within the area of the South Saskatchewan River valley which will soon be permanently under water.

I wish to thank Robert R. Taylor for assisting in this brief mammal "survey".

\section{LITERATURE CITED}

Beck, W. H. 1958. A guide to Saskatchewan mammals. Spec. Publ. \#1, Sask. Nat. Hist: Soc., Regina. $52 \mathrm{pp}$.

Cahalane, V. H. 1947. Mammals of North America. Macmillan Co., New York. 682 pp.

Hall, E. R., and K. R. Kelson. 1959. The mammals of North America. Vol. 11 . Ronald Press Co., New York. pp. 547-1083, + Index.

Nero, R. W. 1958. Additional Pocket Mouse records. Blue Jay, 16:176-179.

Rand, A. L. 1948. Mammals of the eastern Rockies and western plains of Canada. Natl. Mus. Can., Bull. No. 108, Biol. Series No. 35. Ottawa. 237 pp.

Soper, J. D. 1931. Field notes on the Pallid Meadow Mouse, Lagarus pallidus (Merriam). Can. Field-Nat., 45 (9):209-214.

Soper, J. D. 1961. Field data on the mammals of southern Saskatchewan. Can. Field-Nat. 75:23-41.

\section{A COUGAR KILL NEAR KINCAID}

by Tom White, Regina

In late June, 1964, I checked the report of a cougar kill south of Kincaid. A 300-pound calf had been attacked and killed and was examined by the farmer before rigor mortis set in. It was lying on the ground 20 feet from the brush on the edge of the creek and death seemed to have been instantaneous as there was no sign of a struggle. There were deep razor-like claw marks in the shoulders, and wounds in the neck and throat. The body was drained of blood though none had been shed on the ground, and some meat had been eaten from the shoulder. Five other calves had been killed recently all of which were eaten clean and all killed approximately 20 feet from the brush. One calf had been dragged 100 feet by the brisket before it was eaten. During the preceding winter cat tracks-four and a half inches in diameter-with an 18 inch stride were followed for a quarter of a mile and periodically the animal had jumped 20 to 30 feet for no apparent reason.

Wolves, coyotes and feral dogs do not drink their kills dry and cannot kill without a struggle; the bobcat and lynx could not kill without a struggle either, and do not have the capacity to drink a calf dry. All indications point to a series of cougar kills in the Kincaid area in 1964.

\section{MORE LYNX RECORDS}

"I believe there have always been 2. lynx or two arcund this district, especially in the hills southwest of Ethelton. But this year |letter of April 10, 1964l there have been an unusually large number reported. I did not keep the record of those reported in papers but I did talk to farmers and trappers who had shot or trapped them.

"Taking a ten-mile radius arcund Ethelton, this is what I have found: seven trapped by C. Cosman, three by Wm. Lambert, three by H. Selness, two by L. Eros, all in winter; one shot by G. Kearns, one by J. Mitchell, one by F. Duclaux, one by W. Hill, all in summer or fall. Add one with a mutilated foot reported in the Melfort Journal to have been shot in the Pleasant Valley district. We believe this to be a lynx that visited our yard. One rajiny day we found several hens lying around the yard, mauled, slashed and torn so that we had to kill them. We asked H. Selness to catch whatever was killing them, but all he caught was skunks-14 of them Two weeks later more hens were mauled; this time we saw a big grey cat, but were unable to shoot it. A few days later the report of the lynx with the mutilated foot appeared in the paper, and Mr. Selness suggested that it could have been the one which caught our hens as it would be unable to hold on to the hens after catching them.-Genevieve Belliveau, Ethelton.

Editor's Note: It was interesting to see a clipping from the Craik Weekly News with an item from the column "Days that are done" quoting a report of 50 years ago, May 21, 1914 , "A lynx was shot on the Anderson farm west of Reber school." 